\title{
Optimization of the Hemispherical Solar Distiller Performance Augmented by Different Basin Materials (steel, zinc, and copper) and Reflective Mirrors
}

\section{Mohammed El Hadi Attia}

Faculty of Science, University of El Qued

Abd Elnaby Kabeel

Tanta University Faculty of Engineering

Mohamed Abdelgaied ( $\square$ mohamed_abdelgaied@f-eng.tanta.edu.eg)

Tanta University Faculty of Engineering

Abdelkader Bellila

Faculty of Exact Science, University of El Qued

\section{Research Article}

Keywords: Hemispherical solar distillers, Optimal basin materials, Reflective mirror, Energy, Exergy, Economic analysis

Posted Date: November 10th, 2021

DOI: https://doi.org/10.21203/rs.3.rs-488413/v1

License: (c) (1) This work is licensed under a Creative Commons Attribution 4.0 International License.

Read Full License 


\title{
Optimization of the hemispherical solar distiller performance augmented by different basin materials (steel, zinc, and copper) and reflective mirrors
}

\author{
Mohammed El Hadi Attia ${ }^{1}$, Abd Elnaby Kabeel ${ }^{2,4}$, Mohamed Abdelgaied ${ }^{2}$, Abdelkader \\ Bellila $^{3}$, \\ ${ }^{1}$ Department of Physics, Faculty of Science, University of El Oued, 39000 El Oued, AlGERIA \\ ${ }^{2}$ Mechanical Power Engineering Department, Faculty of Engineering, Tanta University, Tanta, \\ EGYPT \\ ${ }^{3}$ LABTHOP Laboratory, Faculty of Exact Sciences, University of El Oued, 3900 El Oued, ALGERIA \\ ${ }^{4}$ Faculty of Engineering Delta, University for Science and Technology, Gamasa, EGYPT \\ *Corresponding author: E-mail address: Mohamed Abdelgaied (mohamed_abdelgaied@f-eng.tanta.edu.eg), \\ Abd Elnaby Kabeel (kabeel6@f-eng.tanta.edu.eg)
}

\section{Abstract}

The present comprehensive study aims to solve the problem of declining drinking water productivity from solar distillers. The hemispherical distillers are characterized by having the large condensing and receiving surface area, so the utilization of basin materials with high thermal conductivity and reflective mirrors are very effective to enhance a cumulative production of hemispherical distillation. To get the optimal basin materials with the reflective mirror that achieves the highest hemispherical distiller's performance, three high thermal conductivity basin materials (steel, zinc, and copper) with reflective mirror were tested at the same conditions and compared to reference hemispherical unit. To realize this idea, four distillers was fabricated and tested at a same climate condition namely: Hemispherical solar Distiller with Black Silicone Walls (HSD-BSW), Hemispherical Solar Distiller with Steel Plate and Reflective Mirror (HSD-SPRM), Hemispherical Solar Distiller with Zinc Plate and Reflective Mirror (HSD-ZPRM), and Hemispherical Solar Distiller with Copper Plate and Reflective Mirror (HSD-CPRM). The experimental results presented that the utilization of copper basin materials and reflective mirror (HSD-CPRM) represents the good option to achieve the highest performance of hemispherical distiller, use the copper basin materials and reflective mirror (HSD-CPRM) gives a cumulative production reached $9500 \mathrm{~mL} / \mathrm{m}^{2}$ day with improvement of $104.3 \%$ compared to reference hemispherical distiller (HSD-BSW). Also, use the copper basin materials and reflective mirror (HSD-CPRM) improves the daily thermal efficiency and exergy efficiency by $102.4 \%$ and $194.9 \%$, respectively compared to HSDBSW. The comprehensive economic analysis concluded that the use of copper basin materials 
and reflective mirrors (HSD-CPRM) reduced the distillate water cost per liter by $44.1 \%$ compared to HSD-BSW.

Keywords: Hemispherical solar distillers; Optimal basin materials; Reflective mirror; Energy; Exergy, Economic analysis.

\section{Introduction}

One of the most important problems afflicting remote desert regions of the world is an acute shortage of safe drinking water. Dry desert areas have a significant stock of salty water that is not suitable for drinking, according to the World Health Organization, and a significant energy reserve is a solar energy (Chandrika et al., 2021; Kabeel and Abdelgaied, 2017; Kabeel and Abdelgaied, 2019). Scientists are turning to renewable energy (solar energy) in all areas of life, including the desalination of saltwater. Solar water desalination is a viable and economical solution to provide safe drinking water (Al-Molhem and Eltawil, 2020; Suraparaju and Natarajan, 2021a; Abdelgaied et al., 2021a; Attia et al., 2021a; Manokar et al., 2018a). Many researchers seek to improve the daily productivity of solar energy distillers, by innovating new designs for distillation devices or by adding the fins (Dhivagar and Mohanraj, 2021; Abdelgaied et al., 2021b; Suraparaju and Natarajan, 2021b), or by adding thermal storage materials (Mohammed et al., 2021; Ramalingam et al., 2021; Kabeel and Abdelgaied, 2016), or by adding some modifications to design solar distillers (Kabeel et al., 2016 ; Kabeel et al., 2019).

Attia et al. (2020) experimentally examined the influences of aluminum foil sheets as an absorber cover on the traditional solar distiller performance of traditional solar distiller. They are observed that the absorber covers in the solar distiller hence decreases the rate of evaporation. The productivity reported for the solar distiller with and without absorber cover (aluminum foil sheet) was $1004 \mathrm{ml} / \mathrm{m}^{2} /$ day and $1528 \mathrm{ml} / \mathrm{m}^{2} /$ day. Because of the negative results, the authors advise not to completely coat the solar distillate with an absorbent coating such as aluminum foil sheets. Panchal and Shah (2016) carried out an experimental analysis to investigate the impact of coupling double solar basin with evacuated tubes (to provide hot water) with/without black granite gravel. They found 56 and $65 \%$ increments in distillate output without and with the use of black granite gravel, respectively, compared to reference unit. Khechekhouche et al. (2021) experimentally conducted improvement of traditional solar distiller using a zinc plate of black metallic. The results presented that the utilization of zinc plates as thermal storage material increases the rate of evaporation. The production reported 
for distiller with/without absorber cover (zinc plate) was $3894 \mathrm{ml} / \mathrm{m} 2 /$ day and 2520 $\mathrm{ml} / \mathrm{m} 2 /$ day. Dwivedi and Tiwari (2010) used different energy-absorbing materials (black rocks, coated sponge, and uncoated sponge) in three same solar distillers and the traditional solar distiller. They found that the use of energy-absorbing materials increased the productivity of solar distillers, they found a $20 \%$ increment in distillate output by use of black rocks, compared with the coated sponge and uncoated sponge and traditional solar distiller. Chandrika et al. (2021) used internal reflectors on a single slope solar distiller. The authors experimentally compared the performance of a solar distiller with a mirror reflector and an aluminum sheet reflector for distilled water augmentation. The authors concluded that a highest production of $5.9 \mathrm{~kg} / \mathrm{m}^{2}$ were collected for single slope solar distiller with mirror reflector and $5.2 \mathrm{~kg} / \mathrm{m}^{2}$ were collected for single slope solar distiller with an aluminum sheet reflector. El-Bialy (2014) studied the experimental of effect floating absorber plate on a single slope and compared it with the traditional solar distiller. He found the rate of improvement in productivity increases when the absorbent plate is above water, and the daily productivity decreases when the mass of water on the absorbent plate increases. Attia et al. (2021b) performed an experiment using materials basins (iron, zinc, and copper) integrated with hemispherical distillers. The authors founded that a production of hemispherical distiller with iron metal basin was $5500 \mathrm{ml} /$ day, with zinc metal basin was $6300 \mathrm{ml} /$ day and with copper, the metal basin was $7350 \mathrm{ml} /$ day. Velmurugan et al. (2008) incorporated fins into the lining of the basin in order to increase the productivity of an individual solar basin. This method increases the surface area of the absorption (still base), and thus, increases the rate of heat transfer between the saltwater and the absorption surface and thus increases the rate of productivity. Omara et al. (2014) fabricated three solar stills (reference type, finned distiller, and corrugated distiller). They found that the productivity of solar panels when using the fins increases by about $40 \%$, and when using the corrugated solar panels, the productivity increases by about $21 \%$ compared to the productivity of traditional distillation. Khechekhouche et al. (2020) experimentally investigated the improvement of traditional solar distiller by using an external refractor, under Algerian climatic conditions. The result was that the external refractor increases the rate of yield distiller. The productivity for the solar distiller with and without an external refractor was $4.8404 \mathrm{~kg} / \mathrm{m}^{2} /$ day and $3.4084 \mathrm{~kg} / \mathrm{m}^{2} /$ day, respectively. Omara et al. (2013) modified the stepped solar distillers by using internal reflectors. The yield of distillates was compared with/without reflectors and the yield of conventional distillates. The percentage improvement in the daily accumulation of stepped solar distillation with/without reflectors was about $75 \%$ and $57 \%$, respectively, compared to 
reference case. Much of the previous works confirmed that the use of external refraction to improve solar distillation devices has improved the productivity of solar stills by a rate ranging from 9-21\% (Tanaka and Nakatake, 2017; Omara et al., 2017; Tanaka, 2009).

The aim of this comprehensive experimental study is to improve the output of solar distillation. Therefore, we are placing black painted steel, zinc, and copper plates at a bottom of basin with reflective mirrors on the inner surfaces of distillate. The presence of metal plates at the bottom of the basin enhanced the heat storage capacity, and a reflective mirror on the inner surfaces of the solar distillate increasing the reflection of the solar irradiation falling in the distillation basin. The hemispherical distillers are characterized by having a large condensing/receiving surface area, so the utilization of basin materials with high thermal conductivity and reflective mirrors are very effective to enhance a cumulative hemispherical distiller's production. To get optimal basin materials with the reflective mirror that achieves a highest hemispherical distiller's performance, three high thermal conductivity basin materials (steel, zinc, and copper) with reflective mirror were tested at the same conditions and compared to a reference case. To realize this idea, four distillers was fabricated and tested at same climate condition namely: Hemispherical solar Distiller with Black Silicone Walls (HSD-BSW), Hemispherical Solar Distiller with Steel Plate and Reflective Mirror (HSDSPRM), Hemispherical Solar Distiller with Zinc Plate and Reflective Mirror (HSD-ZPRM), and Hemispherical Solar Distiller with Copper Plate and Reflective Mirror (HSD-CPRM).

\section{Experimental work}

\section{Experimental setup and description}

The current empirical study aims to enhance a cumulative production of hemispherical distillers. This goal was done by utilizing high thermal conductivity basin materials and an inner reflective mirror. To get the optimal basin materials with the reflective mirror that achieves a highest hemispherical distiller's performance, three high thermal conductivity basin materials (steel, zinc, and copper) were tested at a same condition and compared to a reference case. To realize this idea, four distillers was fabricated and tested at the same climate condition namely: Hemispherical solar Distiller with Black Silicone Walls (HSD-BSW), Hemispherical Solar Distiller with Steel Plate and Reflective Mirror (HSD-SPRM), Hemispherical Solar Distiller with Zinc Plate and Reflective Mirror (HSD-ZPRM), and Hemispherical Solar Distiller with Copper Plate and Reflective Mirror (HSD-CPRM). 
Figures 1 and 2 show the schematic and photo of four hemispherical distillers utilized in this empirical work. In this experiment, we made four hemispherical solar distillers presented in the study, each consists of a circular basin made of wood $50 \mathrm{~mm}$ thick, $0.38 \mathrm{~m}$ diameter, and $40 \mathrm{~mm}$ edge height. These circular basins are covered by a hemispherical transparent cover, which is $3 \mathrm{~mm}$ thick and $0.4 \mathrm{~m}$ in diameter. The effective area of each circular basin is 0.1 $\mathrm{m}^{2}$. The saltwater depth for each hemispherical basin is taken constantly at $0.01 \mathrm{~m}$. The resulting distilled water was collected in the distillate water tank.

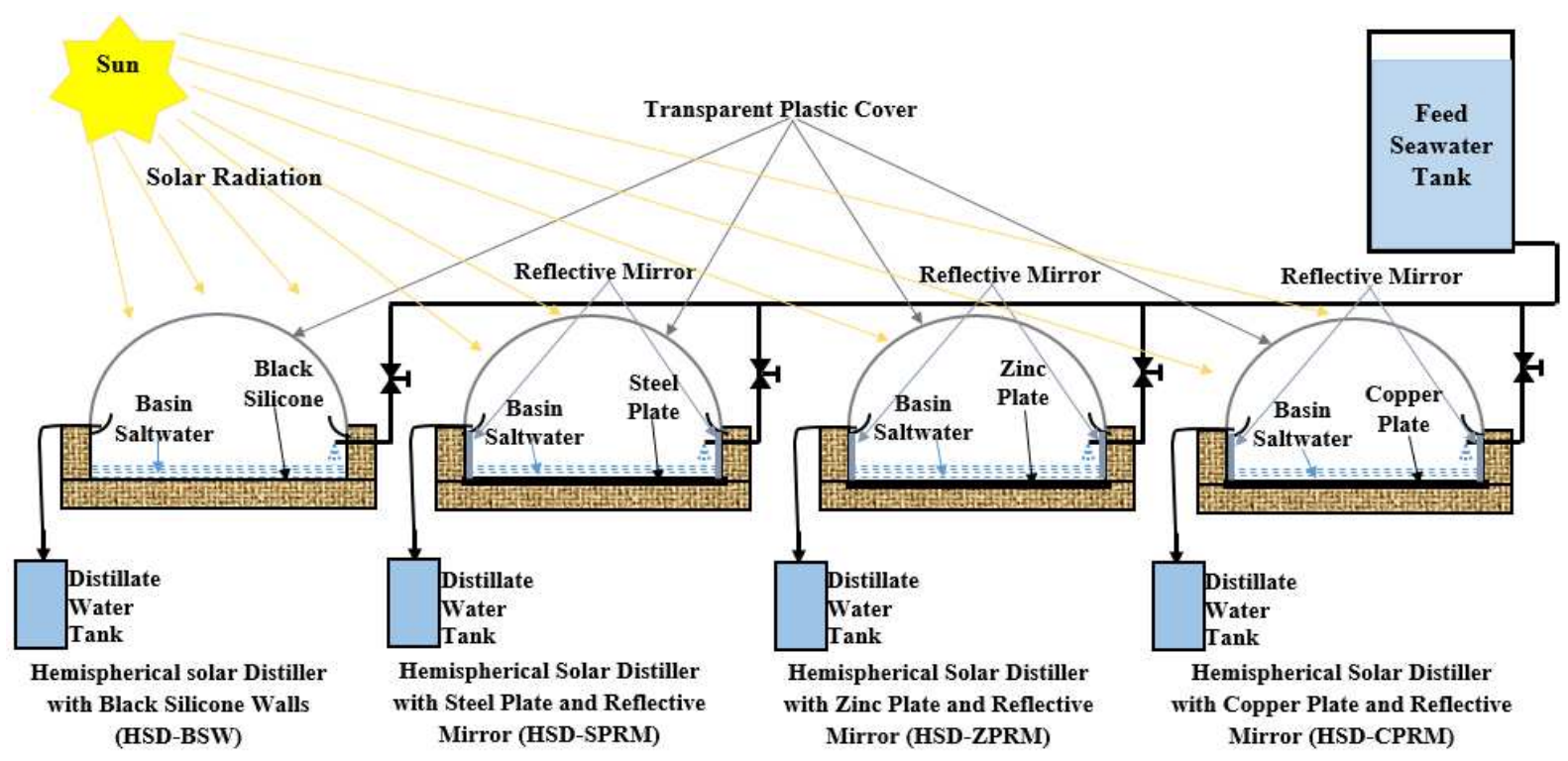

Fig. 1. Schematic presentations of four hemispherical solar distillers.

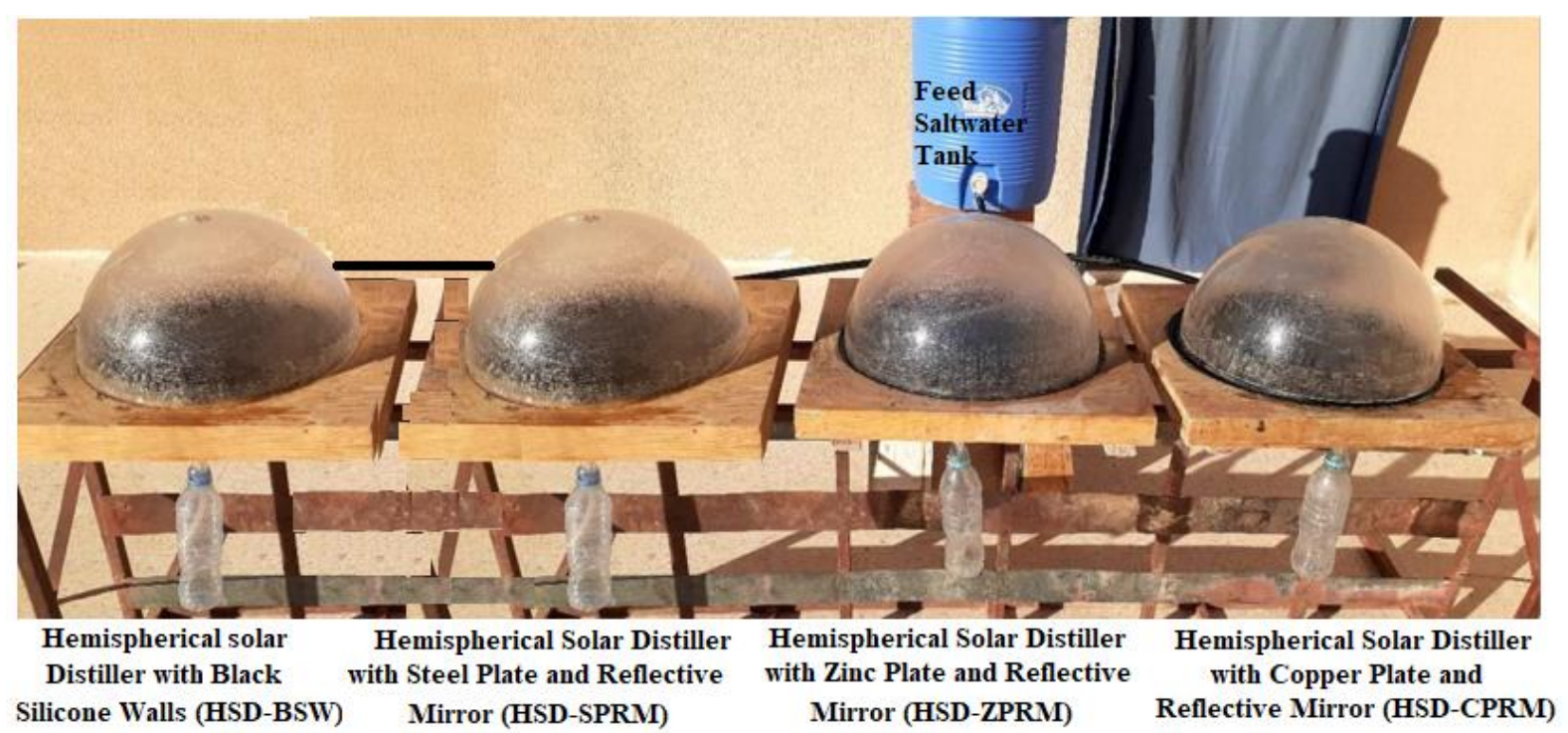

Fig. 2. Photo of the experimental test of four hemispherical distillers. 
Figure 3 shows the basin photo of four hemispherical solar distillers utilized in this empirical work. In this experiment, the basin of Hemispherical Solar Distiller with Black Silicone Walls (HSD-BSW) made from wood and coated by black silicone represents a reference case. In Hemispherical Distiller with Steel Plate and Reflective Mirror (HSD-SPRM), the basin was made from steel plate coated by black paint, and the Reflective Mirror was installed on the vertical side walls. In the Hemispherical Solar Distiller with Zinc Plate and Reflective Mirror (HSD-ZPRM), the basin was made from a zinc plate coated with black paint, and the Reflective Mirror was installed on the vertical sidewalls. In the Hemispherical Solar Distiller with Copper Plate and Reflective Mirror (HSD-CPRM), the basin was made from a copper plate coated with black paint, and the Reflective Mirror was installed on the vertical sidewalls.

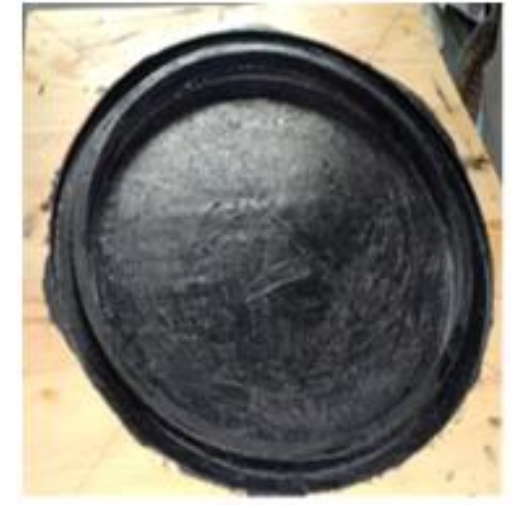

Hemispherical solar Distiller with Black Silicone Walls (HSD-BSW)

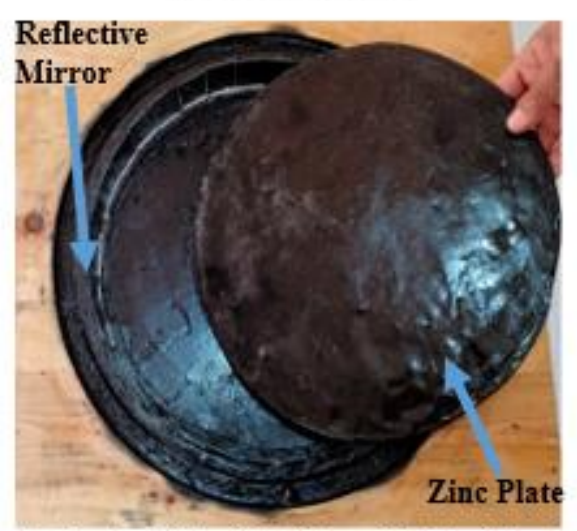

Hemispherical Solar Distiller with Zinc Plate and Reflective Mirror (HSD-ZPRM)

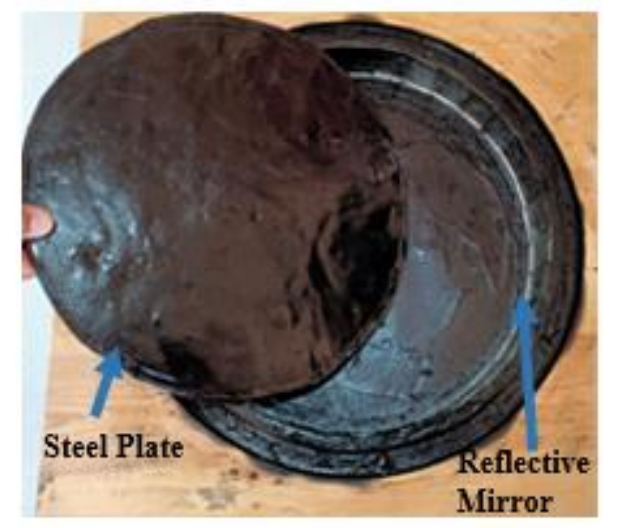

Hemispherical Solar Distiller with Steel Plate and Reflective Mirror (HSD-SPRM)

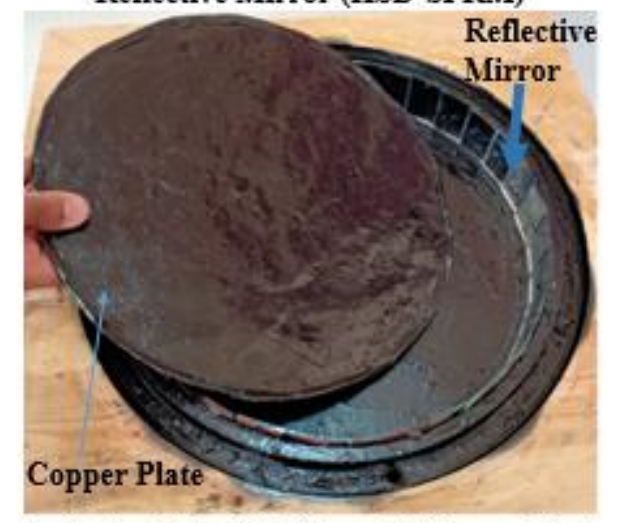

Hemispherical Solar Distiller with Copper Plate and Reflective Mirror (HSD-CPRM)

Fig. 3. Photo of the basin configuration of the four hemispherical distillers. 
170

To achieve the influences of utilizing the basin materials with higher thermal conductivity and the reflective mirror on hemispherical solar distiller's cumulative yield. The four hemispherical solar distillers are namely; HSD-BSW, HSD-SPRM, HSD-ZPRM, and HSDCPRM were tested at the same Algerian ambient conditions. Through the test days, the intensities of solar irradiation and temperatures, and cumulative yield are recorded from 7:00 AM to 6:00 PM.

The temperatures of inner and outer transparent cover hemispherical inside and out, ambient air, basin saltwater, and distillate water are measured by utilizing the K-type thermocouples. The intensity of solar irradiation is measured by a solar meter. By means of a graduated vessel, the distilled water collected in a tank is recorded. The range, accuracy, and standard uncertainty of measuring instrumentations are listed in Table 1.

Table 1 Specifications of measuring instrumentations

\begin{tabular}{lccc}
\hline \multicolumn{1}{c}{ Instrument } & Range & Accuracy & Standard uncertainty \\
\hline Graduated cylinder & $0-500 \mathrm{ml}$ & $\pm 1 \mathrm{ml}$ & $0.5 \mathrm{ml}$ \\
Solar power meter & $0-1999 \mathrm{~W} / \mathrm{m}^{2}$ & $\pm 10 \mathrm{~W} / \mathrm{m}^{2}$ & $5.76 \mathrm{~W} / \mathrm{m}^{2}$ \\
Thermocouple & $-100-500{ }^{\circ} \mathrm{C}$ & $\pm 0.1^{\circ} \mathrm{C}$ & $0.08^{\circ} \mathrm{C}$ \\
\hline
\end{tabular}

\section{System performance}

Daily thermal efficiency $\eta_{\text {daily.th. }}$ of hemispherical distillers calculated as follows:

$$
\eta_{\text {daily.th. }}=\frac{\sum\left(\dot{m}_{d} h_{f g}\right)}{\sum\left(I(t) \times A_{s}\right) \times 3600} \times 100 ; \quad(\%)
$$

where: $\dot{m}_{d}$ is the mass of distillate yield $(\mathrm{kg} / \mathrm{h}) ; \mathrm{I}(\mathrm{t})$ is intensity of solar irradiation $\left(\mathrm{W} / \mathrm{m}^{2}\right)$; $A_{s}$ is absorber surface area $\left(\mathrm{m}^{2}\right)$; and $h_{f g}$ is the latent heat $(\mathrm{J} / \mathrm{kg})$ which calculated as (Kabeel and Abdelgaied 2017):

$$
\begin{aligned}
\mathrm{h}_{f g}=10^{3} \times[ & 2501.9-2.40706 \mathrm{~T}_{\mathrm{w}}+1.192217 \times 10^{-3} \mathrm{~T}_{\mathrm{w}}{ }^{2}-1.5863 \\
& \left.\times 10^{-5} \mathrm{~T}_{\mathrm{w}}{ }^{3}\right]
\end{aligned}
$$




$$
\eta_{\text {exe }}=\frac{\sum E x_{\text {output }}}{\sum E x_{\text {input }}} \times 100,(\%)
$$

$$
E x_{\text {input }}=A_{s} \times I(t)\left[1-\frac{4}{3} \times\left(\frac{T_{a}+273.15}{6000}\right)+\frac{1}{3} \times\left(\frac{T_{a}+273.15}{6000}\right)^{4}\right]
$$

Output exergy from hemispherical distillers Ex output calculated as follows (Manokar et al. 2018b):

$$
E x_{\text {output }}=\frac{\dot{m}_{d} h_{f g}}{3600}\left[1-\frac{T_{a}+273}{T_{w}+273}\right]
$$

where; $\mathrm{T}_{\mathrm{w}}$ is the basin saltwater temperature $\left({ }^{\circ} \mathrm{C}\right), T_{a}$ is ambient air temperature $\left({ }^{\circ} \mathrm{C}\right)$, and $T_{g}$ is glass cover temperature $\left({ }^{\circ} \mathrm{C}\right)$.

\section{Results and discussions}

Climatic conditions represented by solar irradiation and ambient air temperature are the main factors affecting the operation of hemispherical solar distillates. So, it is necessary to record the variations of solar irradiation and ambient air temperature throughout the test day started from 7:00 AM till 7:00 PM. Figure 4 shows the instantaneous variations of solar irradiation and ambient air temperature throughout the operating day during the period starting from 7:00 AM to 7:00 PM. It is evident from the instantaneous variations shows in the figure, the intensity of solar irradiation gradually increases until it reaches the maximum value of 1010 Watt $/ \mathrm{m}^{2}$ at 12:00 AM after that gradually decreases until it reaches zero at sunset. Also, it is evident from the instantaneous variations of ambient air temperature shows in the figure, the temperature of ambient air varying between $32-50^{\circ} \mathrm{C}$ throughout the operating day. 


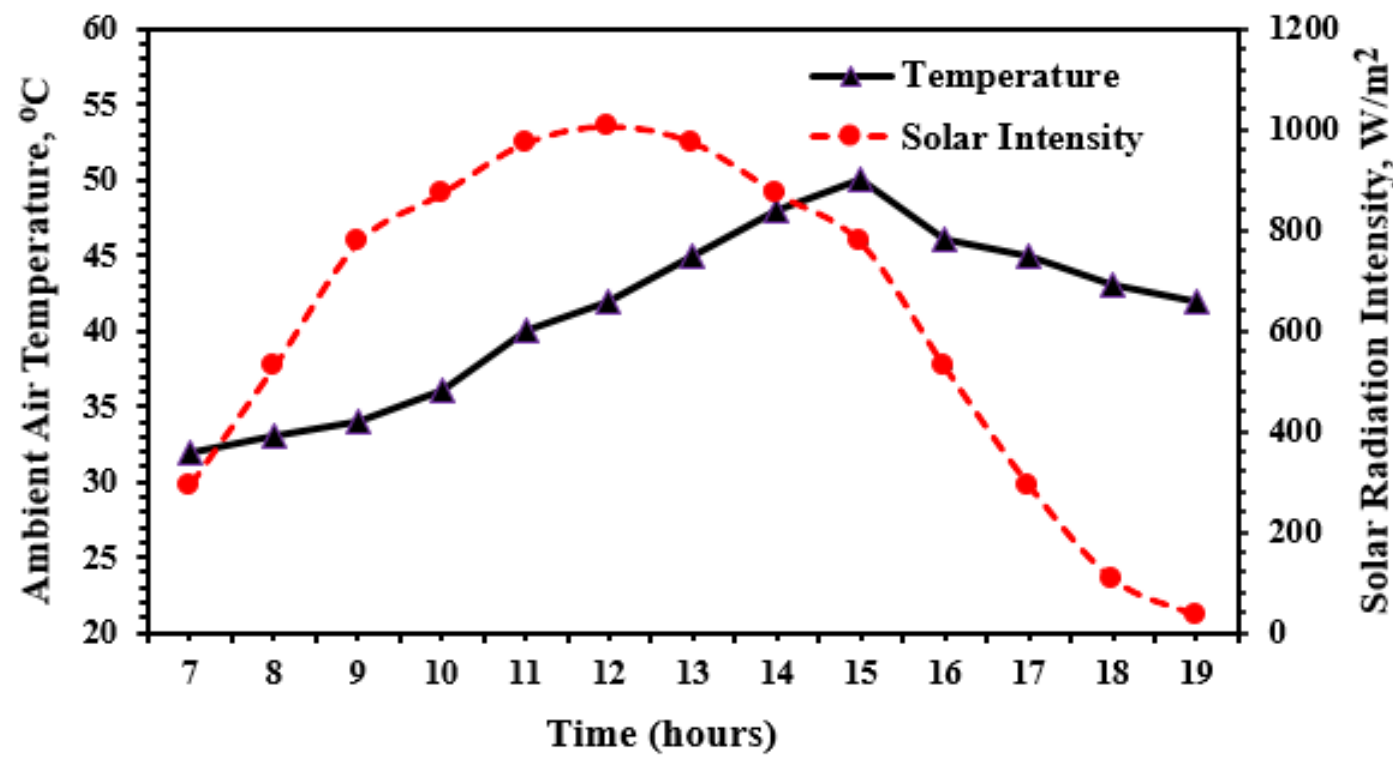

Fig. 4 Hourly variations of ambient temperature and solar irradiation throughout the operating day

To achieve the influences of utilizing the high thermal conductivity basin materials and an inner reflective mirror on the performance of hemispherical solar distillates, as well as, to get the optimal basin materials (steel, zinc, and copper) with the reflective mirror that achieves a highest hemispherical distiller's performance. The instantaneous variations of basin saltwater temperatures were measured for both: Hemispherical solar Distiller with Black Silicone Walls (HSD-BSW), Hemispherical Solar Distiller with Steel Plate and Reflective Mirror (HSDSPRM), Hemispherical Solar Distiller with Zinc Plate and Reflective Mirror (HSD-ZPRM), and Hemispherical Solar Distiller with Copper Plate and Reflective Mirror (HSD-CPRM) during the period from 7:00 AM till 7:00 PM. Where the temperature of the basin saltwater represents an important measure of the evaporation rate inside the basin of the hemispherical solar distiller and thus a measure of the cumulative distillate yield, as the rate of evaporation inside the distillation improves with the increase of the temperature of the saltwater in the basin. Figure 5 shows the utilization of high thermal conductivity basin materials and the reflective mirror has a great influence on the basin saltwater temperature, the temperature of basin saltwater varying between $32-68{ }^{\circ} \mathrm{C}, 32-74{ }^{\circ} \mathrm{C}, 32-76{ }^{\circ} \mathrm{C}$, and $32-78{ }^{\circ} \mathrm{C}$ for HSD-BSW, HSD-SPRM, HSD-ZPRM, and HSD-CPRM, respectively. 


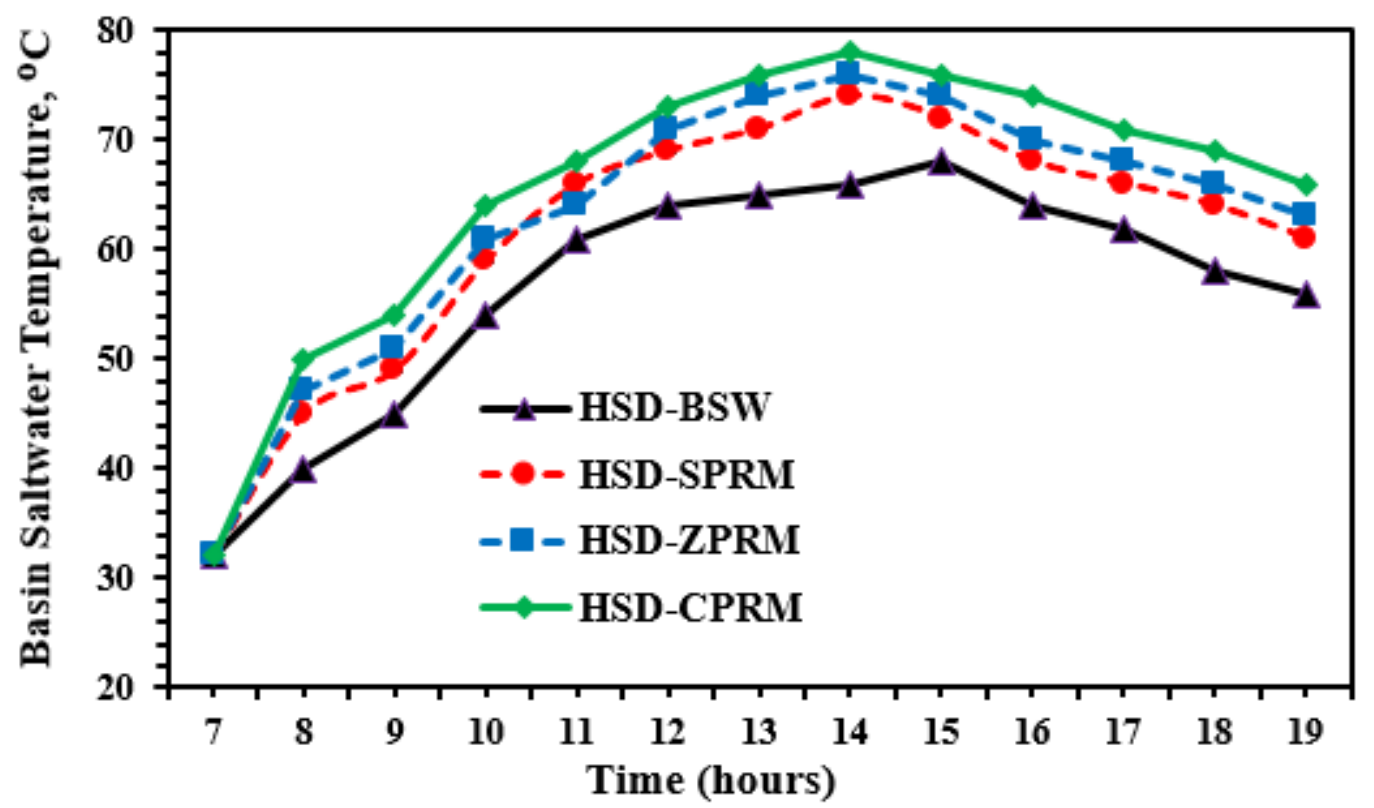

Fig. 5 Hourly temperature variations of basin saltwater within the test day

The heat transfer by convection is the main driver in the solar desalination field. Whereas, the difference in a temperature between basin saltwater and glass cover is a measure of natural buoyancy inside the distillation. As the temperature difference increases, both the buoyancy force and the rate of heat transfer by natural convection will be increases, thus improving the yield of hemispherical solar distillation. Fig. 6 presented the temperature difference $\left(\mathrm{T}_{\mathrm{w}}-\mathrm{T}_{\mathrm{g}}\right)$ through the four hemispherical solar distillers (HSD-BSW, HSD-SPRM, HSD-ZPRM, and HSD-CPRM). As presented in Fig. 6, a temperature difference in reference hemispherical distiller (HSD-BSW) ranged between 1-19 ${ }^{\circ} \mathrm{C}$, while the utilization of steel plate and reflective mirror (HSD-SPRM) improved the temperature difference to $1-24{ }^{\circ} \mathrm{C}$, with improvement varying between $23.5-71.4 \%$ as shown in Fig. 7. While the utilization of zinc plate and reflective mirror (HSD-ZPRM) improved the temperature difference to $1-25{ }^{\circ} \mathrm{C}$, with improvement varying between $15.8-100 \%$ as shown in Fig. 7. While the utilization of copper plate and reflective mirror (HSD-CPRM) improved the temperature difference to 1$26{ }^{\circ} \mathrm{C}$, with improvement varying between $368-142.9 \%$ as shown in Fig. 7. The temperature analysis results evident that the utilization of copper plate and reflective mirror (HSD-CPRM) represent the good obtain to investigate the highest temperature difference and thus will obtain the highest distillate production of hemispherical solar distiller. 


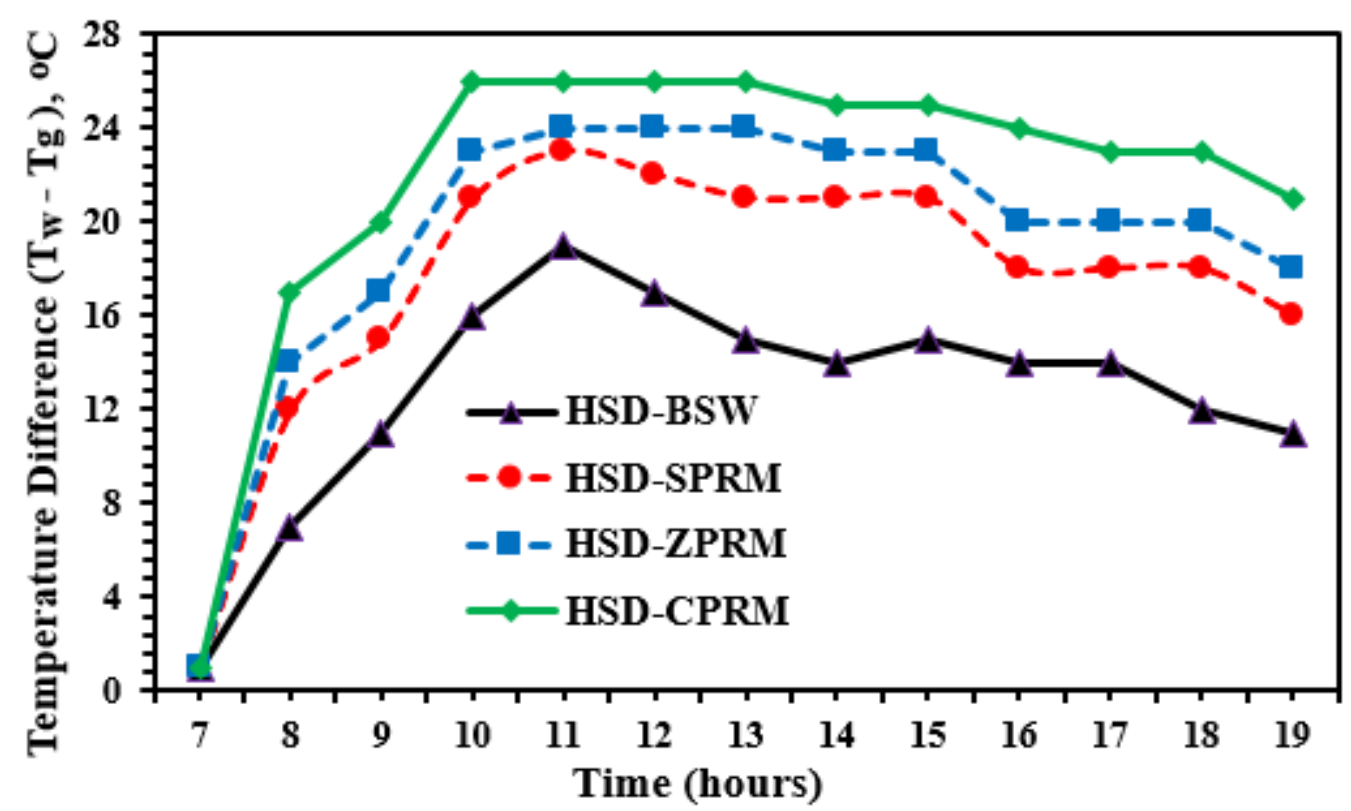

Fig. 6 Temperature difference variation between saltwater and cover within the four hemispherical solar distillers

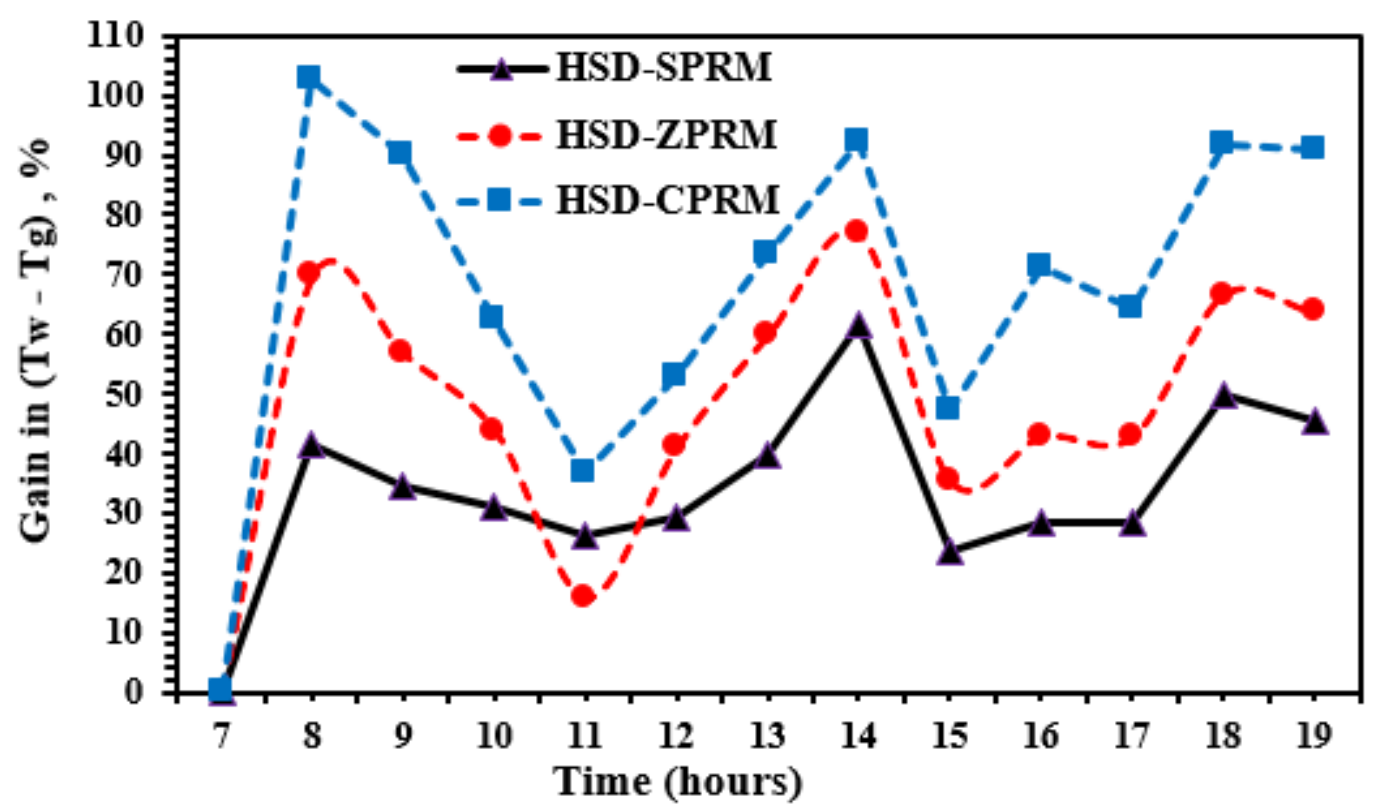

Fig. 7 Effect of high thermal conductivity basin materials and reflective mirror on (Tw-Tg) of hemispherical solar distillers

242 Based on the analysis presented in Figs. (5-7), the utilization of steel plate and reflective mirror (HSD-SPRM) increases the temperature difference ( $\mathrm{Tw}-\mathrm{Tg}$ ) with the rate reached 1.71 times HSD-BSW; while utilization of zinc plate and reflective mirror (HSD-ZPRM) increases 
the temperature difference ( $\mathrm{Tw}-\mathrm{Tg}$ ) with the rate reached 2 times HSD-BSW. But the utilization of copper plate and reflective mirror (HSD-CPRM) increases the temperature difference (Tw-Tg) with the rate reached 2.43 times HSD-BSW. Based on the recorded data of instantaneous distillate yield presented in Fig.8, its found that the instantaneous distillate yield has the same trend for HSD-BSW, HSD-SPRM, HSD-ZPRM, and HSD-CPRM, but at a higher rate in presence of copper plate and reflective mirror (HSD-CPRM). The measured recorded peak instantaneous distillate yield was recorded in 2:00 PM which reached 700, 1000, 1100, and $1150 \mathrm{~mL} / \mathrm{m} 2 \mathrm{~h}$ for HSD-BSW, HSD-SPRM, HSD-ZPRM, and HSD-CPRM, respectively. It is evident from this that the use of copper plate and reflective mirror (HSDCPRM) improved the instantaneous distillate yield of hemispherical solar distillers.

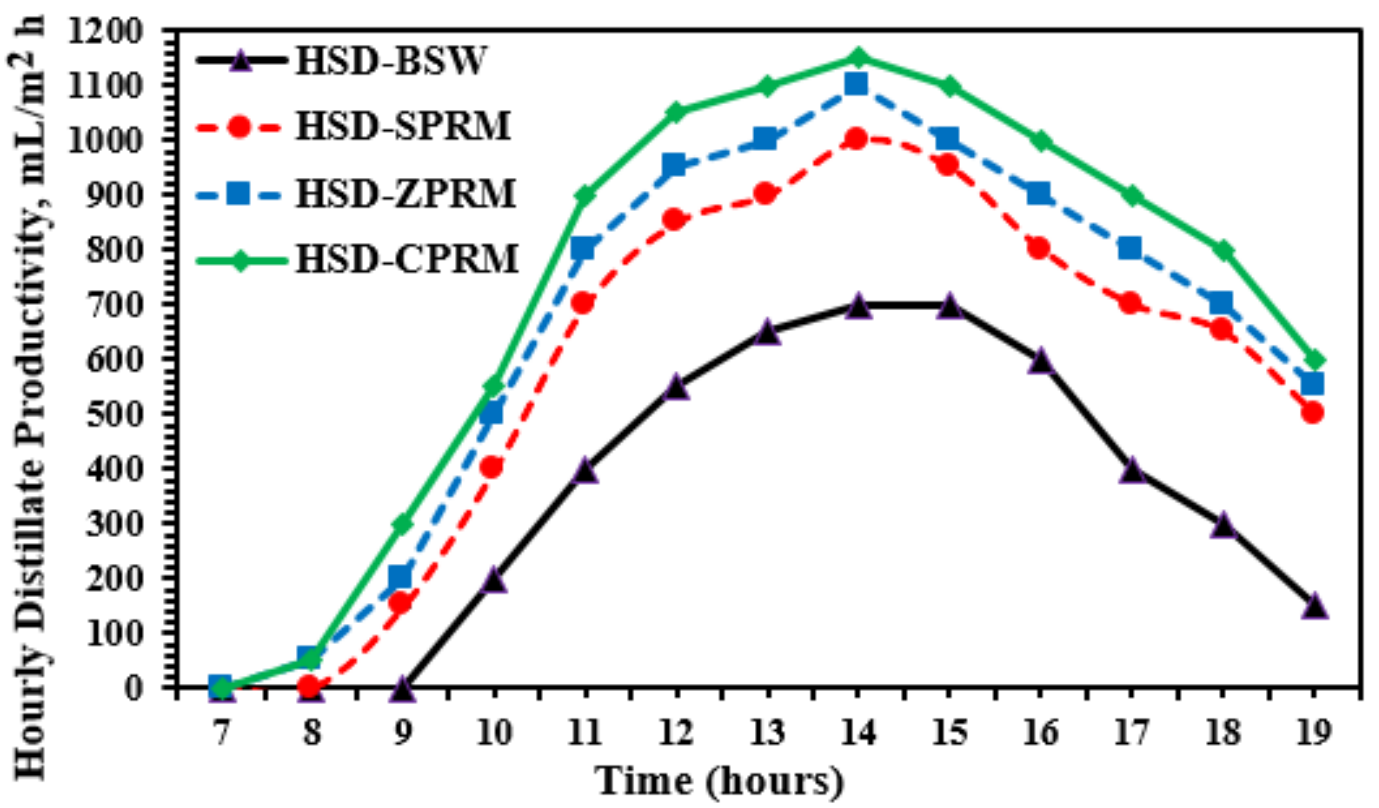

Fig. 8 Instantaneous distillate yield for the four hemispherical distillers

To get optimal basin materials with the reflective mirror that achieves a highest hemispherical solar distiller's performance, Fig. 9 shows cumulative distillate production of four hemispherical solar distillers. As shown in Fig. 9, the utilization of high thermal conductivity basin materials and an inner reflective mirror is the good option, which HSD-SPRM give the high cumulative distillate yield which up to $7600 \mathrm{~mL} / \mathrm{m}^{2}$ day, HSD-ZPRM give cumulative distillate yield which up to $8550 \mathrm{~mL} / \mathrm{m}^{2}$ day, and HSD-CPRM give cumulative distillate yield which up to $9500 \mathrm{~mL} / \mathrm{m}^{2}$ day while the HSD-BSW give $4650 \mathrm{~mL} / \mathrm{m}^{2}$ day. The results presented that the improvement in cumulative distillate yield for utilization of high thermal 
conductivity basin materials and an inner reflective mirror reached 63.4, 83.9, $104.3 \%$ for HSD-SPRM, HSD-ZPRM, and HSD-CPRM, respectively compared to HSD-BSW.

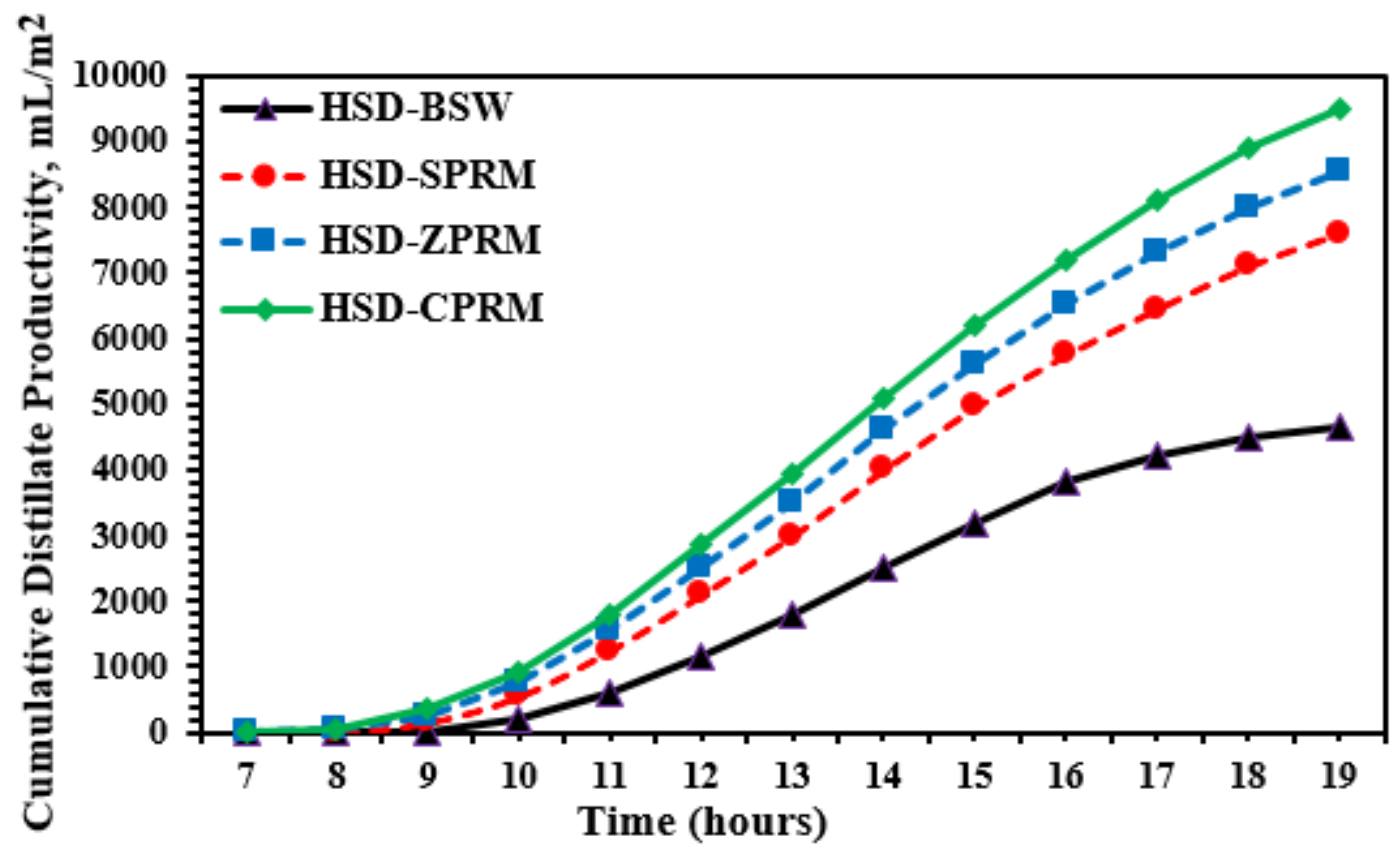

Fig. 9 The cumulative distillate yield for the four solar distillers.

Fig. 10 shown the daily thermal efficiency and exergy efficiency of HSD-BSW, HSD-SPRM, HSD-ZPRM, and HSD-CPRM. As shown the daily thermal efficiency of reference hemispherical distiller (HSD-BSW) reached 38\%, while the utilization of high thermal conductivity basin materials and reflective mirror improved the daily thermal efficiency to $61.9 \%, 69.5 \%$, and $77 \%$ for steel plate and reflective mirror (HSD-SPRM), zinc plate and reflective mirror (HSD-ZPRM), and copper plate and reflective mirror (HSD-CPRM), respectively. Also, Fig. 10 show the exergy efficiency of reference distiller (HSD-BSW) reached $2.24 \%$, while the utilization of high thermal conductivity basin materials and reflective mirror improved the daily thermal efficiency to $4.55 \%, 5.44 \%$, and $6.62 \%$ for steel plate and reflective mirror (HSD-SPRM), zinc plate and reflective mirror (HSD-ZPRM), and copper plate and reflective mirror (HSD-CPRM), respectively. 


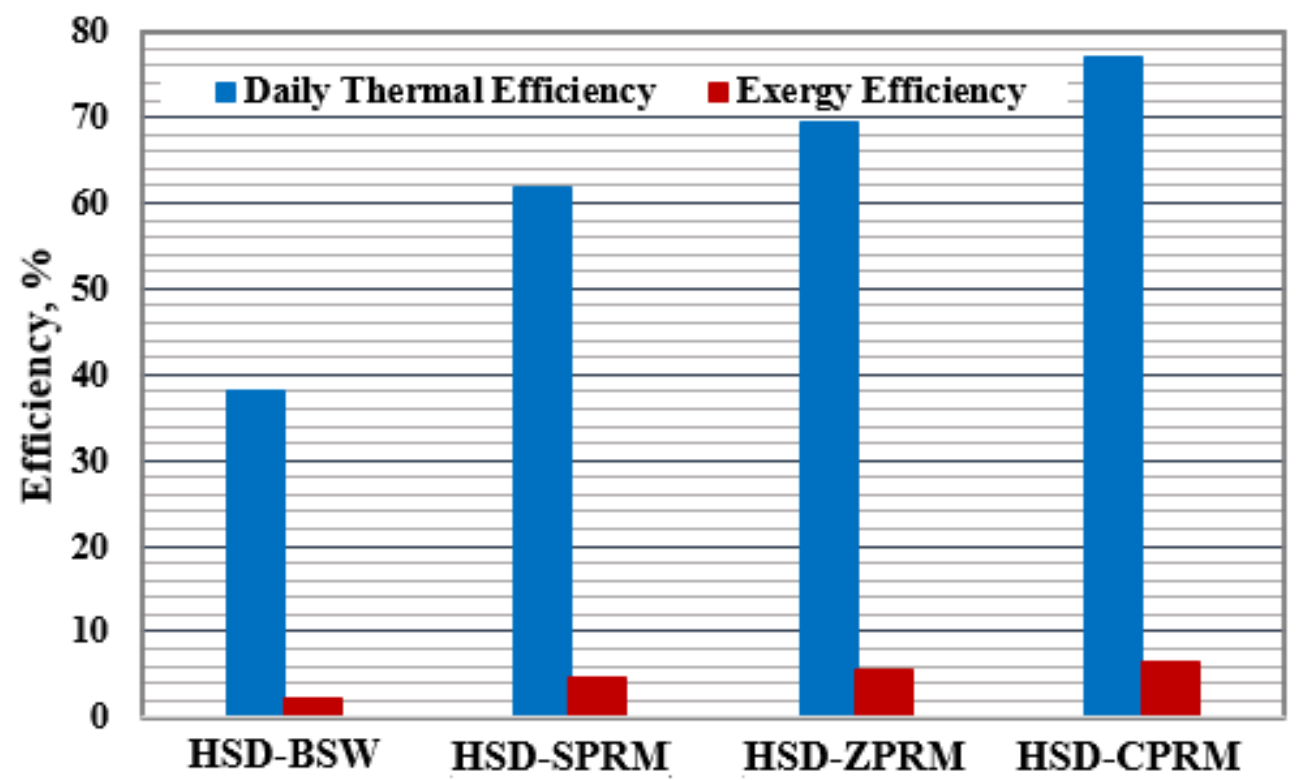

Fig. 10 Daily thermal efficiency and exergy efficiency of HSD-BSW, HSD-SPRM, HSD-

Fig. 11 shows the influences of the utilization of the high thermal conductivity basin materials (steel, zinc, and copper) with reflective mirror on performance improvement of the hemispherical solar distillers. the results presented that the improvement in daily thermal efficiency, exergy efficiency, and cumulative yield reached 62.7, 102.6, and $63.4 \%$, respectively for use of the steel plate and reflective mirror (HSD-SPRM). But for using the zinc plate and reflective mirror (HSD-ZPRM), the improvement in daily thermal efficiency, exergy efficiency, and the cumulative yield reached $82.7 \%, 142.5 \%$, and $83.3 \%$, respectively. While the utilization of copper plate and reflective mirror (HSD-CPRM) represent the good options that improved the daily thermal efficiency, exergy efficiency, and cumulative yield by $102.4 \%, 194.9 \%$, and $104.3 \%$, respectively. 


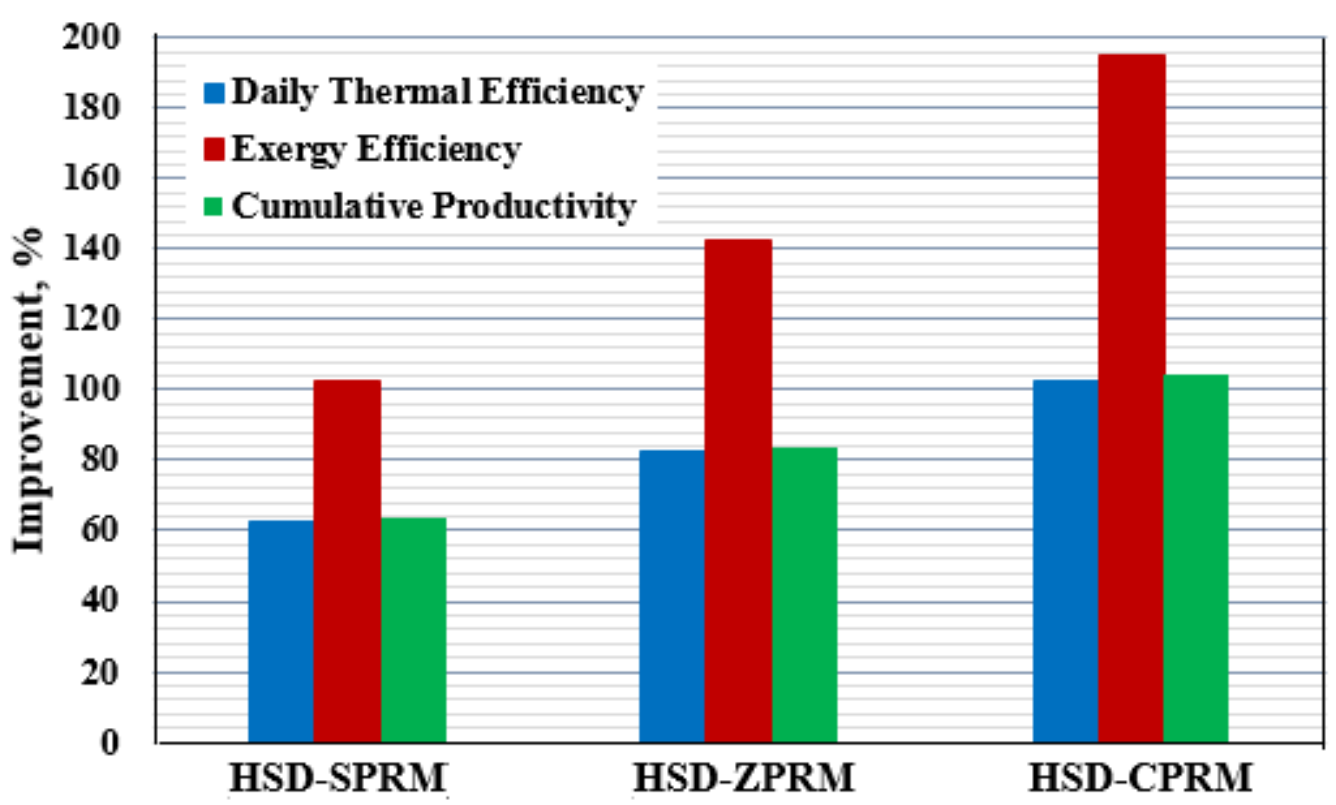

Fig. 11 improvement in daily thermal efficiency, exergy efficiency, and cumulative yield of HSD-SPRM, HSD-ZPRM, and HSD-CPRM

\section{Comparison with published similar works}

To demonstrate the importance of using high thermal conductivity basin materials (steel, zinc, and copper) and reflective mirror and its effect on the performance of hemispherical solar distillates. Table 2 presents a comparison between our results and the results of the amendments proposed in the previous papers. From the results of the comparison, it is clear that the use of high thermal conductivity basin materials (steel, zinc, and copper) with reflective mirrors is very effective for improving the performance of the hemispherical solar distillers.

Table 2 Comparison our results with previous studies

\begin{tabular}{lcc}
\hline \multicolumn{1}{c}{ Authors and reference } & Types of solar distiller & $\begin{array}{c}\text { The rise in } \\
\text { cumulative } \\
\text { yield (\%) }\end{array}$ \\
\hline Khalifa and Ibrahim & Single-Slope SS with internal reflectors & 2.8 \\
$(2011)$ & Single-Slope with external reflectors & 10.56 \\
\hline Kumar et al. (2008) & "V" type SS with Mirror & 11.92 \\
& "V" type SS with Mirror and charcoal & 14.11 \\
\hline
\end{tabular}




\begin{tabular}{lcc}
\hline $\begin{array}{l}\text { Gnanaraj and Velmurugan } \\
(2019)\end{array}$ & Double slope SS with reflector & 93.39 \\
\hline Omara et al. (2013) & Stepped SS with Internal reflectors & 75 \\
\hline Abdullah et al. (2020) & Trays SS with Internal reflectors & 58 \\
& Trays SS with External reflectors & 75 \\
\hline \multirow{2}{*}{$\begin{array}{c}\text { Present experimental } \\
\text { work }\end{array}$} & HSS with Steel plate and reflective mirror & 63.4 \\
& HSS with Zinc plate and reflective mirror & 83.9 \\
& HSS with Copper plate and reflective & 104.3 \\
& mirror & \\
\hline
\end{tabular}

\section{Economic Evaluation}

A comprehensive economic study was conducted to demonstrate the economic feasibility of using high thermal conductivity basin materials (steel, zinc, and copper) with reflective mirrors and the extent of their impact on the total cost of distillates produced from hemispherical solar distillates. The economic analysis was performed using the equations mentioned by Kabeel and Abdelgaied (2017a). Based on the cost analysis shown in Table 3, the total cost of distilled water per liter of HSD-BSW, HSD-SPRM, HSD-ZPRM, and HSDCPRM reached $0.01,0.0071$, and $0.0062 \$ /$ Liter. The comprehensive economic study presented that the total cost per liter of distillate water produced from HSD-SPRM, HSDZPRM, and HSD-CPRM reduced by $33.9 \%, 39 \%$, and $44.1 \%$, respectively compared to HSD-

Table 3 Cost details of HSD-BSW, HSD-SPRM, HSD-ZPRM, and HSD-CPRM.

\begin{tabular}{lcccc}
\hline & HSD-BSW & $\begin{array}{c}\text { HSD- } \\
\text { SPRM }\end{array}$ & $\begin{array}{c}\text { HSD- } \\
\text { ZPRM }\end{array}$ & $\begin{array}{c}\text { HSD- } \\
\text { CPRM }\end{array}$ \\
\hline Capital cost, \$. & 68 & 73.4 & 75.7 & 78 \\
Annual capital cost, \$. & 12 & 12.99 & 13.39 & 13.8 \\
Annual salvage value, \$. & 0.77 & 0.84 & 0.86 & 0.89 \\
Annual maintenance cost, \$. & 3.6 & 3.89 & 4.02 & 4.14 \\
Annual total cost, \$. & 14.83 & 16.04 & 16.55 & 17.05 \\
Annual productivity, & 1256 & 2052 & 2309 & 2565 \\
L/m²/year & & & &
\end{tabular}


$\begin{array}{lllll}\text { Cost of distillat water per } & 0.0118 & 0.0078 & 0.0072 & 0.0066\end{array}$ litres, \$/Liter

\section{Conclusions}

327

The current comprehensive study aims to solve a problem of declining drinking water productivity from hemispherical solar distillers. This goal was done by utilizing high thermal conductivity basin materials and an inner reflective mirror. To get the optimal basin materials with the reflective mirror that achieves a highest hemispherical distiller's performance, three high thermal conductivity basin materials (steel, zinc, and copper) were tested at a same condition and compared to reference case. To realize this idea, four hemispherical distillers was fabricated and tested at a same climate condition namely: Hemispherical solar Distiller with Black Silicone Walls (HSD-BSW), Hemispherical Solar Distiller with Steel Plate and Reflective Mirror (HSD-SPRM), Hemispherical Solar Distiller with Zinc Plate and Reflective Mirror (HSD-ZPRM), and Hemispherical Solar Distiller with Copper Plate and Reflective Mirror (HSD-CPRM). The conclusions can be written as follows:

- The utilization of high thermal conductivity basin materials and reflective mirror give the high cumulative distillate yield which up to 7600,8550 , and $9500 \mathrm{~mL} / \mathrm{m}^{2}$ day for HSDSPRM, HSD-ZPRM, and HSD-CPRM, respectively, while the HSD-BSW give $4650 \mathrm{~mL} / \mathrm{m}^{2}$ day.

- The improvement in cumulative distillate yield for utilization of high thermal conductivity basin materials and reflective mirror reached 63.4, 83.9, $104.3 \%$ for HSD-SPRM, HSDZPRM, and HSD-CPRM, respectively compared to HSD-BSW.

- The comprehensive economic study presented that the total cost per liter of distillate water produced from HSD-SPRM, HSD-ZPRM, and HSD-CPRM reduced by 33.9\%, 39\%, and $44.1 \%$, respectively compared to HSD-BSW.

- Use the copper basin materials and reflective mirror (HSD-CPRM) improves the daily thermal efficiency and exergy efficiency by $102.4 \%$ and $194.9 \%$, respectively compared to HSD-BSW.

The productivity of the distillate with the copper plate and reflective mirror is much better than that of the distillate with steel plate and reflective mirror or zinc plate and reflective mirror. 


\section{Nomenclature}

SS

HSS-BPW Hemispherical Still with Black Painted Walls

HSS-RM Hemispherical Still with a Reflective Mirror

HSS- Hemispherical Still with Steel Plate and Reflective Mirror

SPRM

HSS-

ZPRM

HSS- Hemispherical Still with Copper Plate and Reflective Mirror

\section{Declarations}

Not applicable

Not applicable

Not applicable

-Authors Contributions

\begin{tabular}{crl}
\hline No. & Author's full name & \multicolumn{1}{c}{ Authors Contributions } \\
\hline \multirow{2}{*}{1} & Mohammed El Hadi Attia & $\begin{array}{l}\text { Formal analysis and investigation, Writing - } \\
\text { original draft preparation. }\end{array}$ \\
\hline
\end{tabular}




\begin{tabular}{lll}
\hline \multirow{2}{*}{ Abd Elnaby Kabeel } & Conceptualization, Writing - Review \& \\
& Editing. \\
\hline \multirow{2}{*}{$3 \quad$ Mohamed Abdelgaied } & Conceptualization, Methodology, Writing - \\
& & Review \& Editing. \\
\hline \multirow{2}{*}{4} & Abdelkader Bellila & Conceptualization, Methodology, Writing - \\
& & Review \& Editing. \\
\hline
\end{tabular}

372

-Funding

No any funding used in this paper

\section{-Competing Interests}

No competing interests

\section{-Availability of data and materials}

Not applicable

\section{Reference}

Abdelgaied M, Harby K, Eisa A (2021a) Experimental investigation on the performance improvement of tubular solar still using floating black sponge layer. Environ Sci Pollut Res (2021). https://doi.org/10.1007/s11356-021-13187-z

Abdelgaied M, Harby K, Eisa A (2021b) Performance improvement of modified tubular solar still by employing vertical and inclined pin fins and external condenser: an experimental study. Environ Sci Pollut Res 28, 13504-13514.

Abdullah AS, Younes MM, Omara ZM, F.A. Essa FA (2020) New design of trays solar still with enhanced evaporation methods-Comprehensive study. Solar Energy 203, 164-174.

Al-Molhem YA, Eltawil MA (2020) Enhancing the double-slope solar still performance using simple solar collector and floatable black wicks. Environ Sci Pollut Res 27, 3507835098.

Attia MEH, Kabeel AE, Abdelgaied M, El-Maghlany WM, Driss Z (2021a) Enhancement of the performance of hemispherical distiller via phosphate pellets as energy storage medium. Environ Sci Pollut Res (2021). https://doi.org/10.1007/s11356-021-12920-y 
Attia MEH, Driss Z, Kabeel AE, Abdelgaied M, Manokar AM, Sathyamurthy R, Hussein AK (2020) Performance Evaluation of Modified Solar Still using Aluminum Foil Sheet as Absorber Cover- a Comparative Study. Journal of Testing and Evaluation (JTE), (in press), 2020. https://doi.org/10.1520/JTE20200249.

Attia MEH, Kabeel AE, Abdelgaied M, Essa FA, Omara ZM (2021b) Enhancement of hemispherical solar still productivity using iron, zinc and copper trays. Solar Energy 216, 295-302.

Chandrika VS, Attia MEH, Manokar AM, Marquez FPG, Driss Z, Sathyamurthy R (2021) Performance enhancements of conventional solar still using reflective aluminium foil sheet and reflective glass mirrors: energy and exergy analysis. Environ Sci Pollut Res (2021). https://doi.org/10.1007/s11356-021-13087-2

Dhivagar R, Mohanraj M (2021) Performance improvements of single slope solar still using graphite plate fins and magnets. Environ Sci Pollut Res (2021). https://doi.org/10.1007/s11356-020-11737-5

Dwivedi VK, Tiwari GN (2010) Experimental validation of thermal model of a double slope active solar still under natural circulation mode. Desalination 250(1), 49-55.

El-Bialy E (2014) Performance analysis for passive single slope single basin solar distiller with a floating absorber-An experimental study. Energy 68, 117-124.

Gnanaraj SJP, Velmurugan V (2019) An experimental study on the efficacy of modifications in enhancing the performance of single basin double slope solar still. Desalination 467, 12-28.

Kabeel AE, Abdelgaied M, Almulla N (2016) Performances of pyramid-shaped solar still with different glass cover angles: experimental study, 7th International Renewable Energy Congress (IREC). IEEE, 1-6.

Kabeel AE, Abdelgaied M (2017) Performance enhancement of modified solar still using multi-groups of two coaxial pipes in basin, Applied Thermal Engineering 118, 23-32.

Kabeel AE, Abdelgaied M (2019) Performance enhancement of a photovoltaic panel with reflectors and cooling coupled to a solar still with air injection, Journal of Cleaner Production 224, 40-49.

Kabeel AE, Abdelgaied M (2016) Improving the performance of solar still by using PCM as a thermal storage medium under Egyptian conditions, Desalination 383: 22-28. 
Kabeel AE, Harby K, Abdelgaied M, Eisa A (2019) Effect of graphite mass concentrations in a mixture of graphite nanoparticles and paraffin wax as hybrid storage materials on performances of solar still, Renewable Energy 132, 119-128.

Khalifa AJN, Ibrahim HA (2011) Experimental study on the effect of internal and external reflectors on the performance of basin type solar stills at various seasons. Desalin Water Treat 27, 313-318.

Khechekhouche A, Benhaoua B, Kabeel AE, Attia MEH, El-Maghlany WM (2021) Improvement of solar distiller productivity by a black metallic plate of Zinc as a thermal storage material. Journal of Testing and Evaluation 49(2), 967-976.

Khechekhouche A, Kabeel AE, Benhaoua B, Attia MEH, El-said EMS (2020) Traditional Solar distiller improvement by a single external refractor under the climatic conditions of the El Oued region, Algeria. Desalination and water treatment 177, 23-28.

Kumar BS, Kumar S, Jayaprakash R (2008) Performance analysis of a "V" type solar still using a charcoal absorber and a boosting mirror. Desalination 229(1-3), 217-230.

Manokar AM, Winston DP, Kabeel AE, Sathyamurthy R (2018a) Sustainable fresh water and power production by integrating PV panel in inclined solar still, Journal of Cleaner Production 172, 2711-2719.

Manokar AM, Winston DP, Kabeel AE, Sathyamurthy R (2018b) Sustainable fresh water and power production by integrating PV panel in inclined solar still. Journal of Cleaner Production 172, 2711-2719.

Mohammed AH, Attalla M, Shmroukh AN (2021) Performance enhancement of single-slope solar still using phase change materials. Environ Sci Pollut Res 28, 17098-17108

Omara ZM, Hamed MH, Kabeel AE (2011) Performance of finned and corrugated absorbers solar stills under Egyptian conditions. Desalination 277, 281-288.

Omara ZM, Kabeel AE, Younes MM (2013). Enhancing the stepped solar still performance using internal reflectors. Desalination, 314, 67-72.

Omara ZM, Kabeel AE, Abdullah AS (2017) A review of solar still performance with reflectors. Renew. Sustain. Energy Rev. 68, 638-649.

Panchal HN, Shah PK (2016) Investigation on performance analysis of a novel design of the vacuum tube-assisted double basin solar still: an experimental approach. International Journal of Ambient Energy, 37(3), 220-226.

Ramalingam VK, Karthick A, Jeyalekshmi MPV, Decruz AMMAJ, Manokar AM, Sathyamurthy R (2021) Enhancing the fresh water produced from inclined cover stepped 
absorber solar still using wick and energy storage materials. Environ Sci Pollut Res 28, 18146-18162.

Suraparaju SK, Natarajan SK (2021a) Productivity enhancement of single-slope solar still with novel bottom finned absorber basin inserted in phase change material (PCM): techno-economic and enviro-economic analysis. Environ Sci Pollut Res (2021). https://doi.org/10.1007/s11356-021-13495-4

Suraparaju SK, Natarajan SK (2021b) Experimental investigation of single-basin solar still using solid staggered fins inserted in paraffin wax PCM bed for enhancing productivity. Environ Sci Pollut Res (2021). https://doi.org/10.1007/s11356-020-11980-w

Tanaka H, Nakatake Y (2017) Improvement of the tilted wick solar still by using a flat plate reflector. Desalination 216, 139-46.

Tanaka H (2009) Tilted wick solar still with external flat plate reflector: optimum inclination of still and reflector, Desalination 249, 411-415.

Velmurugan V, Gopalakrishnan M, Raghu R, Srithar K (2008) Single basin solar still with fin for enhancing productivity. Energy Convers Manag 49, 2602-2610. 